\title{
From Empire to Humanity: The Russian Famine and the Imperial Origins of International Humanitarianism
}

\section{Tebila Sasson}

\begin{abstract}
This article investigates the imperial origins of international humanitarianism in the British and international relief mission to Russia during the famine of 1921-1922. The famine triggered the first large-scale international humanitarian mission beyond the scope of the European and American empires. Imperial expertise and knowledge became central to the British as well as international humanitarian response to relieve hungry Russia. From international coordination to national campaigns, British politicians and voluntary aid workers relied on imperial tools and thought. The British involvement in the relief mission to Russia thus provides a fresh perspective on the development of internationalist and nationalist humanitarian projects in the interwar period and their relationship to imperial legacies. Through humanitarian aid, Britain assumed a new role on a global stage. By retooling imperial expertise, humanitarian ethics became part of a project of global governance. Furthermore, with the advice of former colonial experts, a "mixed economy" of voluntary and state aid underlay the collaboration between voluntary and international agencies throughout the famine and after. The history of famine relief provides a case study in the emergence of humanitarian governance in the twentieth century.
\end{abstract}

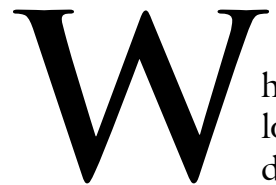

hen he returned from Russia on 16 February 1922, the British colonial administrator Sir Benjamin Robertson reported that the conditions in that famine-stricken country were "very much like those familiar to me in India." Based on extensive experience from his service in the Bombay Presidency and in the Central Provinces for over thirty-five years, Robertson had been sent to Russia as "the world's biggest famine authority." 2 From 8 to 26 January 1922, he visited the famine regions in the Volga district and met with international and local aid workers. His task was to investigate the conditions in Russia and advise an international humanitarian relief mission. "In India when famine

Tehila Sasson is a Past \& Present Postdoctoral Fellow at the Institute for Historical Research, London. For their valuable suggestions at various stages of research and writing this piece, she would like to thank Emily Baughan, Hilary Falb, Aidan Forth, Kevin Grant, Seth Koven, Thomas Laqueur, William Roger Louis, Ben Siegel, Susan Pedersen, Julia Shatz, Sarah Stoller, James Vernon, and the editors of the Journal of British Studies.

1 "Briton Praises A. R. A. Relief Work: Sir Benjamin Robertson, Indian Famine Expert, Tell of Observations in Russia," New York Times, 16 February 1922.

${ }^{2}$ Nellie Gardner, "Russian Famine the Worst," New York Times, 2 April 1922; The Lord Archbishop of Canterbury, Speech to the House of Lords, 23 February 1922, Parliamentary Debates, Lords, 5th series, vol. 49 (1922), cols. 213-31. 
comes the Government has a comparatively easy task," he claimed. ${ }^{3}$ But never before had relief been given to a foreign country on such a scale, let alone to an enemy. Providing international relief to Russia required a global approach to organization: an international system that would coordinate relief by multiple agencies across a large territory.

The Russian famine relief effort of 1921-1922 became the first large-scale international humanitarian mission beyond the scope of the European and American empires. In the aftermath of the First World War, famines became not only a colonial but also a European problem. Although Britain had dealt with large-scale famines in Ireland and India in the second half of the nineteenth century, it was only after the First World War that an elaborate infrastructure of relief work was created beyond its empire. ${ }^{4}$ Mass displacement and hunger gave rise to dozens of voluntary associations aimed at relieving these conditions in Central and Eastern Europe. ${ }^{5}$ The postwar years saw the emergence of organizations aimed at providing relief to Austria and Germany, but it was in Russia that an international famine relief mission was coordinated between voluntary and national relief agencies as well as the League of Nations. In the wake of two dismal harvests and several years of war, the Russian famine was the largest in Europe in more than sixty years, responsible for the deaths of six million people. ${ }^{6}$ Despite the harsh economic conditions in postwar Europe, the international relief mission fed over seven million people daily. ${ }^{7}$ The scale of the effort demanded the participation of a large array of national and international agencies including the League of Nations, Herbert Hoover's American Relief Administration, and voluntary organizations from Great Britain, Sweden, and Germany.

The British involvement in the relief mission to Russia may seem, at first glance, a marginal tale within the broader postwar relief and reconstruction movements in Central and Eastern Europe. In actuality, however, it is illuminating for what it teaches us about aid, power, and sovereignty and for what it reveals about the origins of modern humanitarianism. The story sheds light on the colonial origins of the development of internationalist and nationalist humanitarian projects in the interwar period. While more recent historians of the international order have accounted for the role of the League of Nations in the relief of the Russian famine, ${ }^{8}$

\footnotetext{
3 "Briton Praises A. R. A. Relief Work."

${ }^{4}$ Rebecca Gill, Calculating Compassion: Humanity and Relief in War, Britain 1870-1914 (Manchester, 2013).

${ }^{5}$ See Tara Zahra, The Lost Children (Cambridge, MA, 2011), 24 46. For other relief schemes see also Michelle Tusan, "Crimes against Humanity': Human Rights, the British Empire, and the Origins of the Response to the Armenian Genocide," American Historical Review 119, no. 1 (February 2014): 47-77. For earlier relief missions in Russia and China on a much smaller scale see Richard G. Robbins, Famine in Russia, 1891-1892: The Imperial Government Responds to a Crisis (London, 1975), 175; Cormac Ó Gráda, Famine: A Short History (Oxford, 2009), 23; Pierre Fuller, "Decentering International and Institutional Famine Relief in Late Nineteenth-Century China: In Search of the Local," European Review of History: Revue Européenne D’histoire 22, no. 6 (November 2015): 873-89.

${ }^{6}$ Serguie Adamets, "Famine in Nineteenth- and Twentieth-Century Russia: Mortality by Age, Cause, and Gender," in Famine Demography: Perspectives from the Past and Present, ed. Tim Dyson and Cormac Ó Gráda (New York, 2002), 157-80.

7 Ó Gráda, Famine, 223.

${ }^{8}$ See Bruno Cabanes, The Great War and the Origins of Humanitarianism, 1918-1924 (Cambridge, 2014).
} 
scholars have yet to fully grasp how international expertise developed and from where it originated. The famine created a new international role for Britain through the practice of humanitarian aid. Although British relief efforts in Russia were second to American efforts in their size, ${ }^{9}$ the British were crucial to the internationalization of famine expertise.

The British experience of famines not only informed their own agencies but also came to shape the practice of modern humanitarianism more widely. Drawing from materials in the archives of British voluntary organizations and the government, the League of Nations, and the American Relief Administration, this article shows how Britain's extensive experience with famine relief in its empire provided a set of principles for the internationalization of humanitarian aid for disasters such as famines. By adopting these principles, interwar humanitarianism inherited an ethics of relief that was originally developed to govern the populations of Ireland and India. Once put within an international context, these humanitarian ethics became part of a project of global governance. The relief mission to Russia, therefore, serves as a case study for the emergence of what the anthropologist Didier Fassin has called "humanitarian reason." 10

In telling this story, this article draws on international histories and shows how interwar humanitarianism was not opposed to imperialist thought, but rather built upon it. ${ }^{11}$ It adds to a growing body of scholarship that investigates how, from the late eighteenth century to the Second World War, humanitarianism was dependent upon British imperial identities, ideals, and networks. ${ }^{12}$ Rather than looking

\footnotetext{
${ }^{9}$ At the peak of the relief mission, the American Relief Administration had handled 800,000 tons of cereals, milk, and other foods; medical supplies; and clothing, and mobilized resources worth $\$ 60$ million. Ó Gráda, Famine, 223. The history of the relief efforts has largely been told through the lens of the relationship between the United States and the Soviet Union; see David C. Engerman, Modernization from the Other Shore: American Intellectuals and the Romance of Russian Development (Cambridge, MA, 2003); Benjamin M. Weissman, Herbert Hoover and Famine Relief to Soviet Russia, 1921-1923 (Stanford, 1974); Bertrand M. Patenaude, The Big Show in Bololand: The American Relief Expedition to Soviet Russia in the Famine of 1921 (Stanford, 2002); Merle Curti, American Philanthropy Abroad (New Brunswick, 1988), 279-93; and Emily S. Rosenberg, "Missions to the World: Philanthropy Abroad," in Charity, Philanthropy, and Civility in American History, ed. Lawrence J. Friedman and Mark D. McGarvie (Cambridge, 2003), 241-58.

${ }^{10}$ Didier Fassin, Humanitarian Reason: A Moral History of the Present (Berkeley, 2011), 1-21.

${ }^{11}$ Susan Pedersen, The Guardians: The League of Nations and the Crisis of Empire (Oxford, 2015); Mark Mazower, Governing the World: The History of an Idea (New York, 2012), 119-53; idem, "An International Civilization? Empire, Internationalism and the Crisis of the Mid-Twentieth Century," International Affairs 82, no. 3 (May 2006): 553-66; Glenda Sluga, Internationalism in the Age of Nationalism (Philadelphia, 2013); Patricia Clavin, Securing the World Economy: The Reinvention of the League of Nations, 1920-1946 (Oxford, 2013); Frank Trentmann, "After the Nation-State: Citizenship, Empire and Global Coordination in the New Internationalism, 1914-1930," in Beyond Sovereignty: Britain, Empire and Transnationalism, c. 1880-1950, ed. Philippa Levine, Frank Trentmann, and Kevin Grant (Basingstoke, 2007).

${ }^{12}$ See Michael Barnett, Empire of Humanity: A History of Humanitarianism (Ithaca, 2011); Rob Skinner and Alan Lester, "Humanitarianism and Empire: New Research Agendas," Journal of Imperial and Commonwealth History 40, no. 5 (December 2012): 729-47; Emily Baughan, "The Imperial War Relief Fund and the All British Appeal: Commonwealth, Conflict and Conservatism within the British Humanitarian Movement, 1920-25," Journal of Imperial and Commonwealth History 40, no. 5 (December 2012): 845-61; Ellen Boucher, "Cultivating Internationalism: Save the Children Fund, Public Opinion, and the Meaning of Child Relief, 1919-24," in Brave New World: Imperial and Democratic Nation-Building in Britain between the Wars, ed. Laura Beers and Geraint Thomas (London, 2012), 169-88; Ellen Boucher, Empire's Children: Child Emigration, Welfare, and the Decline of the British World, 1869-1967
} 
exclusively at institutional continuities, however, I follow scholars such as Timothy Mitchell and show that humanitarian aid was the product of expert knowledge and of imperial governance. ${ }^{13}$ During the relief mission to Russia, numerous Western voluntary organizations utilized the expert knowledge and techniques of famine relief first elaborated by the liberal imperialism of the late nineteenth century. ${ }^{14}$ The international relief mission to Russia shows, then, that interwar humanitarianism was based on not only the idea of empire but also its practice.

Furthermore, this story of expertise also reveals that the history of state and non-state aid cannot be easily separated. A "mixed economy" of voluntary and state aid became the foundation for the collaboration of voluntary and international agencies on a global stage. The history of famine relief provides a complex view of the relationship between governmental and nongovernmental humanitarianism: it shows that in practice advisors, inspectors, and other experts worked in both types of agencies at different points in their careers. In this respect the Russian famine gave rise to the first generation of experts who gained their knowledge in the empire and then moved to advise international agencies like the League of Nations, the World Health Organization, and the Food and Agriculture Organization. ${ }^{15}$ It became the testing ground for many international aid organizations in the twentieth century.

\section{HUMANITY AFTER VICTORY}

The Russian relief efforts initially began in 1919 as part of a reconstruction scheme for Central and Eastern Europe in the aftermath of the First World War. British and American organizations already provided relief supplies to Central and Eastern European countries. In early February 1920, these relief missions expanded further east when British organizations - among them the Russian Relief and Reconstruction Fund (under the presidency of Lord Robert Cecil), the Women and Children of Russia Relief Fund, Lady Muriel Paget's Mission to Eastern Europe, and the British Young Men's Christian Association-established posts to provide relief in Moscow and other areas even before a famine was officially declared. ${ }^{16}$ That

\footnotetext{
(Cambridge, 2014); Alan Lester and Fae Dussart, Colonization and the Origins of Humanitarian Governance: Protecting Aborigines across the Nineteenth-Century British Empire (Cambridge, 2014); Matthew Hilton, "Ken Loach and the Save the Children Film: Humanitarianism, Imperialism, and the Changing Role of Charity in Postwar Britain," Journal of Modern History 87, no. 2 (June 2015): 357-94; Keith David Watenpaugh, Bread from Stones: The Middle East and the Making of Modern Humanitarianism (Berkeley, 2015).

${ }_{13}$ Timothy Mitchell, Rule of Experts: Egypt, Techno-Politics, Modernity (Berkeley, 2002). Consider also the work of James Scott in this context, in James C. Scott, Seeing Like a State: How Certain Schemes to Improve the Human Condition Have Failed (New Haven, 1998).

${ }^{14}$ Helen Tilley, Africa as a Living Laboratory: Empire, Development, and the Problem of Scientific Knowledge, 1870-1950 (Chicago, 2011); Joseph Hodge, Triumph of the Expert: Agrarian Doctrines of Development and the Legacies of British Colonialism (Athens, OH, 2007).

${ }^{15}$ See also Tehila Sasson, "Milking the Third World? Humanitarianism, Capitalism and the Nestle Boycott," American Historical Review (forthcoming).

${ }^{16}$ EJ 198/A410, Save the Children Funds Archives (hereafter SCFA).
} 
winter, rumors began to spread about drought and harvest failures in various Russian regions. ${ }^{17}$ In early 1921, as reports on drought persisted, the harbingers of famine became unmistakable.

By summer 1921, the full dimensions of the disaster became apparent. What had begun in November 1920 as a series of harvest failures in postrevolutionary Russia had become, by spring 1921, a catastrophic famine that endangered the lives of more than thirty-seven million people. The Volga region, one of the most important sources of food supply to Russia and the rest of Europe, was experiencing a serious famine. ${ }^{18}$ Reports of starvation and large-scale peasant migration and rumors of cannibalism began circulating. The crisis had in fact reached such a magnitude that it left the new Soviet government no option but to request foreign aid. On 2 July the Russian Central Executive Committee announced the impending appointment of the All-Russian Famine Relief Committee, a public relief agency consisting mostly of celebrities such as the author Maxim Gorky and the artist Constantin Stanislavski, aimed at attracting Western support. Eleven days later, Gorky appealed to the international community for aid. ${ }^{19}$

International responses came fairly quickly. On 10 August 1921, the Allied Supreme Council met in Paris to determine appropriate action. While the Allies opposed the new Bolshevik government, all agreed that the horrors in the east could not be ignored. As Lloyd George, the British prime minister, argued, the famine was so severe that relief became "not a political but a humanitarian" issue $^{20}$ - a necessary response to "the most terrible devastation which has afflicted the world for centuries." 21 The Allied Supreme Council therefore formed an international commission to discuss the coordination of these relief efforts, and voluntary agencies from Britain, the United States of America, Germany, and Sweden sent aid workers to the Volga region. ${ }^{22}$

The coordination of different international relief bodies and agencies was unprecedented and required a new international method of organization. The issue was not only ideological but also technical: the harsh winter conditions in Russia and the lack of a transportation system that would carry food and medical supplies required a network of experts who could administer relief on such difficult terrain. While the League of Nations could reach a diplomatic agreement with the Russians, even that organization admitted that there was a need for specialists with particular knowledge in famine relief. ${ }^{23}$ Thus, the Allied Supreme Council turned to the British, who had developed a systematic approach to famine relief based on their extensive

\footnotetext{
${ }^{17}$ For how the Russian Central Executive Committee and the Eighth All-Russian Congress of Soviets rejected an elaborate relief see Charles M. Edmondson, "The Politics of Hunger: The Soviet Response to Famine, 1921," Soviet Studies 29, no. 4 (October 1977): 506-18.

${ }^{18}$ Lord Emmott, Speech to the House of Lords, 23 February 1922, Parliamentary Debates, cols. 213-31.

19 "Russia Appeal Letter," 1921, EJ 981, SCFA; B. M. Weismann, Herbert Hoover and Famine Relief to Soviet Russia, 1921-1923 (Stanford, 1974), 71.

20 "Allies to Co-Operate for Russian Relief," New York Times, 11 August 1921.

${ }^{21}$ Quoted in "Russian Children at Death's Door," Glasgow Herald, 31 December 1921.

${ }^{22}$ Stephen White, The Origins of Detente: The Genoa Conference and Soviet-Western Relations, 1921-1922 (Cambridge, 2002), 32.

23 "How to Help in the Russian Famine," Spectator, 16 September 1921.
} 
experience with the large famines in Ireland and India from 1846 onwards and which had been codified in the Famine Code of $1880 .{ }^{24}$

The Famine Code offered a centralized form of relief based on scientific knowledge and measurements aimed at reducing starvation at a minimum cost. It established the definition of the emergency and its geographical and human scope and licensed the suspension of laws under the duty to save lives. As such, the code helped to reproduce the basic condition of political sovereignty: concealing the relation between the sovereign's violence and its subjects' bare lives, dissimulating the direct action of power over the subjects' bodies. ${ }^{25}$ The Famine Code created a tension between governance and humanitarian care. It also generated new knowledge of aid and a new class of famine experts, who were in charge of administering the governance of life under threat. It was these experts who helped mold international humanitarianism during the Russian Famine of 1921-1922.

In their August 1921 meeting, Lloyd George proposed that the Allied Supreme Council rely on the advice and services of the British foreign secretary, Lord George Curzon, who as viceroy of India between 1899 and 1905 had experience addressing famines on a large scale. Known for his stringent policies in the famine camps of 1899-1901, Curzon was the architect of a "brilliantly organized famine." 26 Based on this imperial experience, he suggested that relief be organized systematically by dividing the famine area into districts, allocating districts to controllers, avoiding oversupply in any district, rationing food carefully, and establishing hospital and rest houses for the sick. Curzon might not have been an ardent believer in internationalism, but he was a pragmatist, and managing populations in a methodical and efficient manner was his prime concern. Curzon considered three conditions essential for the success of a large international mission: first, the assistance of the Soviet government; second, the formation of an international relief authority; and finally, the enlistment of men with experience who had a zeal for saving lives and a genius for organization, such as those who had worked with Hoover or those the British Empire could supply from India and elsewhere. ${ }^{27}$

While the Russian famine was catastrophic in its size and magnitude, Lord Anthony MacDonnell stated the following day, "if any Government or if any system is capable of coping with it, that system is the one which was elaborated in

\footnotetext{
${ }^{24}$ On the history of the famine code, see James Vernon, Hunger: A Modern History (Cambridge, 2007); Hari Shanker Srivastava, The History of Indian Famines and the Development of Indian Famine Policy, 18581918 (Agra, 1968); Mike Davis, Late Victorian Holocausts: El Niño Famines and the Making of the Third World (London, 2002); and Aidan Forth, Barbed Wire Imperialism: Britain's Empire of Camps, 18761903 (Berkeley, forthcoming). On humanitarianism and empire see also Kevin Grant, A Civilised Savagery: Britain and the New Slaveries in Africa, 1884-1926 (New York, 2005), and Richard Sheldon, "Development, Poverty and Famines: The Record of British Empire," in Development and Colonialism: The Past in the Present, ed. Mark Duffield and Vernon Hewitt (Oxford, 2009).

${ }^{25}$ Carl Schmitt, Political Theology: Four Chapters on the Concept of Sovereignty (Cambridge, MA, 1985); Giorgio Agamben, Homo Sacer (Stanford, 1998); Ernesto Laclau, "Bare Life or Social Indeterminacy," in Giorgio Agamben: Sovereignty and Life, ed. Matthew Calarco and Steven DeCaroli (Stanford, 2007), 11-22.

${ }^{26}$ Davis, Late Victorian Holocausts, 162-75, at 164.

27 "Allies to Co-operate for Russian Relief." See also National "Hands off Russia" Committee, Russian Famine: Mr. Hoover's Sinister Role in Hungary (London, 1921).
} 
India." 28 MacDonnell himself had been working under Curzon's administration as the head of the Famine Commission in India in 1901. He saw the main problem arising from famines to be the management of large numbers of people and migration. "Nothing is more difficult in dealing with famine than reckoning with people who are wandering in large crowds," he stressed. Looking back upon his own experience in India, MacDonnell suggested "to establish large famine camps on the great lines of migration, keeping the people there until measures were taken to bring them back to their villages." 29 The camps were to provide the space both to systematically feed the population-based on utilitarian ideals of distribution that empowered local government-and to manage a large and potentially diseased population. Thus, as in the Indian famines, relief camps would function as both efficient relief tool and a means to combat cholera and typhus, two of the biggest causes of mortality during famines. ${ }^{30}$

MacDonnell was not the only one who feared migration and the spread of diseases in its wake. Lord Asquith saw the Russian famine as a demographic and health threat that would endanger Europe and the British Empire. He stated, "[w]hether the States on the borders of Russia have sufficient medical comforts, disinfectants and doctors to prevent the breaking of the first line of defence by diseased persons and by carriers of disease I do not know."31 Echoing a broader colonial anxiety in the period, Asquith recognized that famine left the affected population relatively defenseless against infectious disease. Relief, therefore, was offered not only because of shared sympathy toward the suffering masses in Russia but also because it became a way to protect Europe from them. ${ }^{32}$

Following Curzon's suggestions, the Allied Supreme Council formed the International Commission on the Russian Famine, which resembled the imperial model used in India. The commission was set to "conduct preliminary enquiries and to co-ordinate the sporadic efforts now being made to render assistance by various Governments and peoples."33 It consisted of thirty representatives of Britain, France, Italy, Belgium, and Japan (with the Americans attending only in the capacity of observers $)^{34}$ chosen for their special knowledge of famine, transport, sanitation, and

${ }^{28}$ Anthony MacDonnell, Speech to the House of Lords, 11 August 1921, Parliamentary Debates, cols. 505-16.

29 Ibid.

${ }^{30}$ On these contradictions in the Indian famine camps see Forth, Barbed Wire Imperialism.

${ }^{31}$ Lord Asquith, Question to the House of Lords, 11 August 1921, Parliamentary Debates, cols. 505-16.

${ }^{32}$ Lynn McDonald, Florence Nightingale at First Hand: Vision, Power, Legacy (London, 2010), 166. On infectious diseases and colonial medicine, see David Arnold, Colonizing the Body: State Medicine and Epidemic Disease in Nineteenth-Century India (Berkeley, 1993); Mark Harrison, Public Health in British India: Anglo-Indian Preventive Medicine, 1859-1914 (Cambridge, 1994); Mark Harrison, "A Question of Locality: The Identity of Cholera in British India, 1860-1890," in Warm Climates and Western Medicine: The Emergence of Tropical Medicine, 1500-1900, ed. David Arnold (Amsterdam, 1996), 133-59; Sheldon Watts, "From Rapid Change to Stasis: Official Responses to Cholera in British-Ruled India and Egypt 1860 to c. 1921," Journal of World History 12, no. 2 (Fall 2001): 321-74.

${ }^{33}$ The National Archives (hereafter TNA), CAB 23/26/22, "Conclusions of a Meeting of the Cabinet," 15 August 1921.

${ }^{34}$ TNA, FO 9440/8614/38, Esmond Ovey on Behalf of Lord Curzon to Lieutenant Colonel J. Ward, 18 August 1921. 
agriculture. This group of experts was accompanied by administrative agents, Red Cross men, and interpreters.

In their first meeting in Paris on 30 August, the British representatives-led by Philip Lloyd-Gkesakb, the parliamentary secretary of the Department of Overseas Trade, and Sir John Hewett, the lieutenant-governor of the United Provinces in India-listed major fields of inquiry: the extent of migration and epidemic disease; food reserves and the surplus of crops available for utilization in the famine area; and the measures being taken by the Soviet government. ${ }^{35}$ The list was then sent to Moscow and signed by Joseph Noulens, the head of the commission. However, the Russians were reluctant to accept them. As the foreign minister Georgy Chicherin's reply from 7 September suggests, the Russians were highly suspicious of the authenticity of the relief. While the principals specified in the letter all manner of information the Allies wanted to collect from Russia, they provided no real commitment to the level of aid they would actually give. Furthermore, Chicherin saw the appointment of Noulens as the head of the commission as an insult, since as a French diplomat he had worked against the Russian Revolution. ${ }^{36}$ To the foreign minister, the commission seemed more concerned with collecting data on Soviet Russia as a counterinsurgency measure than with providing humanitarian assistance. $^{37}$

The failure of the commission therefore left the coordination of the humanitarian mission in the hands of the League of Nations and voluntary organizations. Between 15 and 18 August, the International Committee of the Red Cross and the League of Red Cross Societies convened representatives of a wide variety of European humanitarian organizations to determine the coordination of aid. However, even there, it was former imperial expertise that became central to planning relief. In the opening session, Sir Claude Hill, the director general of the League of Red Cross Societies, was invited to give a speech based on his experience in Bombay during the famine of 1899-1901. As the secretary to Lord Henry Northcote, the governor of Bombay, Hill's experience of the Indian famines left a vivid and painful mark on the memory of his days in India. The deserted villages, cholera in the relief camps, and "the grisly skeletons of the dead bullocks" in Bombay profoundly affected him. According to his memoirs, the famine tragedy brought out "the spirit of humanity and pity which ignores all barriers of race and colour."38 It was this experience with famine relief that led him to found the Indian Red Cross and later to join the League of the Red Cross Societies. ${ }^{39}$

As one of the few famine experts active in the voluntary mission to Russia in 1921, Hill advised voluntary bodies to plan their relief mission in cooperation with governments. In his speech at the Geneva conference he stressed that "the Indian experience definitely shows that if there is to be successful combatting of famine conditions over a widespread area, unity of action must be observed and also only governments and

35 Ibid.

${ }^{36}$ TNA, CAB 24/127/86 "Report on International Commission on the Russian Famine"; TNA, CAB 24/128/20, "The Russian Famine."

${ }^{37}$ Harold Henry Fisher, The Famine in Soviet Russia, 1919-1923: The Operations of The American Relief Administration (London, 1927), 67.

${ }^{38}$ Claude Hill, India: Step-Mother (Delhi, 1929), 115-19, at 117.

39 Ibid. 
government agents can handle the problem authoritatively and successfully." 40 While believing in the importance of the voluntary work of organizations like the Red Cross, Hill nevertheless emphasized the importance of official power in organizing relief: "Most voluntary societies exist and depend on the emotions for they deal with those whom Kipling had described as "poor but very wise in tears." 41 For Hill, a productive international relief effort should consist of collaboration between governmental and non-governmental actors working together to provide aid. Voluntary agencies were merely a supplement, while feeding people and the management of relief were the responsibility of governmental and intra-governmental agencies. From its earliest days, interwar humanitarianism was conceived as part of a mixed economy of aid-a shared effort-rather than exclusively the prerogative of non-governmental relief.

Hill's advice also echoed the imperial anxieties of "famine wanderers" as a dangerous insurgent force associated with political disorder, tribal criminality, and the spread of disease. Unity in relief, for Hill, meant that spatial organization of transportation and population was the key to success for the entire relief mission. In his view, there must be complete control of transportation in order to secure adequate management of a famine area; this would guarantee the shipments of grains and other foodstuff to the relief areas and prevent immigration. ${ }^{42}$ Organization of transportation and enclosed spaces for relief provided both aid and protection from postrevolutionary Russia: they not only distributed rationed food but also detained "unruly" migrants. Hill's suggestions bore more than structural similarities to the Indian Famine Code and the Victorian ethics epitomized in institutions such as the famine camps. According to Hill "[i]t is not sufficient to feed the people and leave them in idleness, it is also necessary to supply them with other resources at suitable centers" so that when the next season comes, they will be able to get back to work. ${ }^{43}$ Relief, in other words, should not be purely gratuitous but rather a tool for selfgovernance. ${ }^{44}$ Hill's suggestions resonated with a Victorian approach to aid, aiming to reduce hunger through a system that could keep people alive without making them dependent. ${ }^{45}$

Hill's suggestions were eventually implemented in the formation of the Comité International Secours a la Russie, an umbrella body created by the conference to administer and coordinate relief work between the various national and voluntary relief bodies working in Russia. ${ }^{46}$ As Curzon had suggested, the committee divided the famine area into zones of relief and the Norwegian doctor Fridtjof Nansen, the League of Nations' high commissioner for Russian refugees, was appointed by the Comité International Secours a la Russie as the high commissioner for famine relief and was empowered to open negotiations with Chicherin immediately.

\footnotetext{
40 "Starvation in Russia First Conference (Red Cross)," 15 August 1921, C1382/R/304/1/C, League of Nations Archive (hereafter LNA).

41 Ibid.

${ }^{42}$ On famine wanderers see Forth, Barbed Wire Imperialism.

43 "Starvation in Russia First Conference (Red Cross)," 15 August 1921, C1382/R/304/1/C, LNA.

44 Ibid.

${ }^{45}$ James Vernon, "The Ethics of Hunger and the Assembly of Society: The Techno-Politics of the School Meal in Modern Britain," American Historical Review 110, no. 3 (June 2005): 693-725.

46 Ibid.
} 
Nansen's involvement was supposed to ensure support for famine relief work from the League of Nations' council. Furthermore, Chicherin also hoped that Nansen would help Russia petition for trade credits, and in return for his cooperation with the League of Nations allow the Russian government to buy additional grain from other European countries.

While the plan for trade credits did not come through, ${ }^{47}$ Nansen visited Russia in late August 1921 and helped divide the areas of relief between the multiple agencies. Faithful to his agreement with the Russians, Nansen did not bring any foreign official to organize the relief although, as one report argued, he was still interested in appointing a British "supervisor and controller." 48 The areas of Saratov on the Volga were allocated to the Save the Children Union, of which the most important element was the Save the Children Fund of the United Kingdom, while the British Friends' Emergency and War Victims Relief Committee received the Buzuluk area east of the Volga. The America Relief Administration and the Red Cross were put in charge of providing relief in the remaining areas. ${ }^{49}$ Coordinated by the League of Nations, not Britain, and working through famine camps and relief houses as Curzon had proposed earlier, these organizations provided the main aid on the ground. ${ }^{50}$

\section{BRITISH HUMANITARIANISM AND THE “THIRD BRITISH EMPIRE"}

The connection between Britain's imperial experience and the advent of international humanitarianism did not end with high-policy planning of the international relief mission to Russia. It also played a role in shaping the vision and collaboration between voluntary organizations and what the historian John Darwin has called the "Third British Empire." 1 British voluntary organizations like the Imperial War Relief Fund and Save the Children Fund saw in places like Australia and Canada a way to extend imperial and international concerns, and finance the humanitarian relief mission to Russia.

In August 1921, prominent public figures and politicians-among them the archbishop of Canterbury, the Conservative politicians Lord Robert Cecil and Arthur Stanley, and the right-leaning Liberal Lord Alfred Emmott-had already signed a joint appeal "to stir the British people to generous national effort," and join the struggle "to save life and alleviate pain." 52 The appeal declared that no nation had suffered

${ }^{47}$ See also BEVERIDGE/7/90/3-4, London School of Economics Archive (hereafter LSEA).

${ }^{48}$ Quoted in "How to Help."

49 "Starvation in Russia 2nd conference (Red Cross)," C1382/R/304/3, LNA; "Starvation in Russia First Conference (Red Cross), Decisions and Resolutions," C1382/R/304/1/B, LNA; "Starvation in Russia. 2nd Conference, Repository Documents," C1382/R/304/2/A, LNA.

50 "Famine in Russia," R1754/47/19846/19810, LNA.

${ }^{51}$ John Darwin, "A Third British Empire? The Dominion Idea in Imperial Politics," in The Oxford History of the British Empire, vol. 4, The Twentieth Century, ed. Judith Brown and W. Roger Louis (New York, 1999); John Darwin, The Empire Project (Cambridge, 2009). See also Mrinalini Sinha, "Whatever Happened to the Third British Empire? Empire, Nation Redux," in Writing Imperial Histories, ed. Andrew S. Thompson (Manchester, 2013), and Duncan Bell, The Idea of Greater Britain: Empire and the Future of World Order, 1860-1900 (Princeton, 2007).

52 "The Russian Famine," Spectator, 12 August 1921. 
more terribly in the war than Russia, and asked Britons to include the country in "the healing gift of sympathy." 53 Cecil, Stanley, and Emmott launched the appeal by the Imperial War Relief Fund, a humanitarian effort active between March 1920 and September 1925; its patron was the king. ${ }^{54}$ While the fund operated mostly as a collecting society, ${ }^{55}$ it was an influential organization with a clear mission: to consolidate an empire-wide humanitarian response to suffering in postwar Europe. The fund provided grants to various organizations administrating famine relief on the continent-most prominently to the British Red Cross operation in Russia-and in return these organizations agreed to distribute relief under a British flag and to cease the publications of their own advertisements. ${ }^{56}$

Within a week of the Imperial War Relief Fund's inauguration, appeals were sent via the Colonial Office to the prime ministers of the White Dominions of Australia, Canada, New Zealand, and South Africa, as well as to the government of India. The fund saw itself as an imperial rather than a local body that would work in collaboration with the League of Nations. ${ }^{57}$ The fund's supporters also regarded collecting donations from across the empire as a way for Britain to be "stirred to a friendly and convincing rivalry," and compete with the scale of American humanitarian relief. ${ }^{58}$ For figures like Emmott, British aid was necessary for keeping the balance of power, and maintaining Britain's international role. ${ }^{59}$ According to one newspaper, British aid workers in Russia "have done more for the prestige of Great Britain than a fleet of battle-ships."60

The British Empire also played a central role for the recently founded organization, Save the Children, and their humanitarian relief mission to Russia. ${ }^{61}$ The "Third British Empire" provided a source of support and solidarity across territorial boundaries for a large-scale relief mission. ${ }^{62}$ Canada was "particularly generous" in the appeal for the Russian famine. ${ }^{63}$ Founded initially as a colonial offshoot of Save

53 Ibid.

54 Baughan, "The Imperial War Relief Fund and the All British Appeal."

${ }^{55}$ I use "mostly" because some of the students affiliated to the work of the IWRF volunteered on the ground in the Saratov area to provide aid and assist the various societies in administering their relief. For more details see BEVERIDGE/7/90/4, LSEA.

${ }^{56}$ DF 1004/ 746, "What is the IWRF?," Appeal leaflet, British Museum Archives (hereafter BMA).

57 TNA, T161/164 15175/1, Governor General of Canada to the Secretary of State for the Colonies, 3 February 1922. See also examples in R815/12B/5030/4479/4-8, LNA; R815/12B/4664/4479/5, LNA; TNA, CO 323/881/32; TNA, CAB 23/26/23.

${ }^{58}$ TNA, CO 323/881, Letter by James Roll, the Mayor of London, to the Dominions and India, 16 August 1921. See also the Marquess Curzon of Kedleston, Speech to the House of Lords, 23 February 1922, Parliamentary Debates, cols. 213-31.

${ }^{59}$ Lord Emmott, Speech to the House of Lords, 11 August 1921, Parliamentary Debates, cols. 505-16.

${ }^{60}$ Correspondent, "Russian Famine," Daily Telegraph, 25 July 1922.

${ }^{61}$ For histories of Save the Children see Emily Baughan, Saving the Children: Humanitarianism, Internationalism and Empire, c. 1918-1970 (Berkeley, forthcoming); Boucher, "Cultivating Internationalism"; Hilton, "Ken Loach and the Save the Children Film"; Linda Mahood, Feminism and Voluntary Action: Eglantyne Jebb and Save the Children, 1876-1928 (New York, 2009); Edward Fuller, The Right of the Child (Boston, 1951).

${ }^{62}$ BEVERIDGE/7/90/5, "Annual Report," 1924, Save the Children Funds, LSEA.

${ }^{63}$ Quote in Dorothy Buxton and Edward Fuller, The White Flame: The Story of the Save the Children Fund (London, 1931), 29. See also Edward Fuller, "Canada and the Children: How the Dominion Heard the Cry from Russia,” World's Children (December 1921): 261. As Lord Weardale, a Liberal politician and the chairman of the British Save the Children admitted, "we are meeting with a splendid 
the Children, the first national Canadian committee of Save the Children was established in 1922 out of the Russian appeal, and was led by Colonel Herbert J. Mackie, a veteran of the First World War. Mackie was able to communicate to Canadians thanks to his close associations with the press, especially with his friend Charles A. Bowman, the editor in chief of the widely read Ottawa Citizen from 1922 to $1923 .{ }^{64}$

The Canadian contribution was not confined to voluntary organizations but was also influenced by the British Foreign Office. The colonial secretary informed the governor general that it would be inadvisable for Canada to confine its contributions to Save the Children. He strongly recommended that financial and material help be apportioned, according to Ottawa's wishes, between Save the Children and the Russian Famine Fund (the latter administered by the British Red Cross and the Society of Friends). ${ }^{65}$ Through the Foreign Office, the British government remained highly involved not only in the humanitarian (and nongovernmental) British response to the Russian famine, but also in its empire. ${ }^{66}$ The mixed economy of state and voluntary relief was supported and funded by the "Third British Empire."

\section{THE PROBLEM OF CREDIBILITY}

Not everyone in Britain agreed with this type of imperial and international aid to the Red Russians. Many were highly suspicious of the Bolsheviks, fearing that aid might be seen to legitimize the Bolshevik government and endorse communism. ${ }^{67}$ For some the idea of giving relief to the enemy while people were starving in Ireland or Cornwall seemed utterly unfair. Rumors circulated that the Bolsheviks were using food supplies to support the Red Army. Some argued the famine was a deliberate attempt by the "wicked Russians" to starve their people as part of the revolution. Others believed that "the Famine did not come as a surprise to the Soviet Government" and they therefore deserved little if any help. One article in the Spectator described this problem: "Unfortunately, in the present case people are holding back from subscribing for the victims of the Russian famine because they are in a state of real confusion and doubt." 68 In a period of instability-revolts across the

response from all parts of the Empire, and Canada in a way peculiarly her own." Lord Weardale to C. A. Bowman as reprinted in Ottawa Citizen, 18 January 1923, 2.

${ }^{64}$ See Colonel Herbert J. Mackie quoted in Save the Children Fund "Christmas Appeal-Appalling Horror of Russian Famine,” Ottawa Citizen, 22 December 1921, 18; C. A. Bowman, Ottawa Citizen, December 1921; idem, "Opportunity to Save Lives," Ottawa Citizen, 6 February 1922; "Save The Children' Fund's Organization,” Monetary Times, 26 May 1922.

${ }^{65}$ Aloysius Balawyder, Canadian-Soviet Relations between the World Wars (Toronto, 1972), 52.

${ }^{66}$ Save the Children was also later endorsed by Lord Curzon EJ 197/410, Curzon to Weardale, 23 November 1921, SCFA; "Money for Russia: Lord Curzon and the Save the Children Fund," Daily Express, 25 November 1921; "Money for Russia: Lord Curzon and the Save the Children Fund," Daily Express, 26 November 1921.

67 The Russian Liberation Committee, The Famine (London, 1922).

68 "The Russian Famine," Spectator, 16 September 1921; "The Russian Famine: Moment Ill-Chosen to Appeal for Fund," Daily Express, 17 November 1921; "Folly of Feeding Russia: All Our Resources Are Needed at Home," Daily Express, 19 November 1921; "The Other Famine," Daily Express, 23 November 1921; "The Famine within Our Gates: Cornwall Suffers while Russia Benefits," Daily Express, 23 November 1921; "Feeding the Red Guards: Truth about Russian Famine Relief at Last," Daily Express, 9 December 1921. 
empire, economic crisis at home, major cuts to public expenditure, and widespread unemployment and poverty-a humanitarian mission to an enemy country like Russia needed to be justified. ${ }^{69}$ Aid organizations required the deployment of new "humanitarian narratives" that would offer a certain level of evidence and generate empathy among the British and international public. ${ }^{70}$

Film became one medium that newly founded charities like Save the Children used to gain support for their relief. While it was undergoing much public scrutiny during its Russian campaign ${ }^{71}$ the charity commissioned the first humanitarian film as a way to showcase the true misery and magnitude of the disaster in Russia. ${ }^{72}$ Humanitarian imagery was, of course, not new in 1921. From the mid-nineteenth century onward, visual representations of human suffering became a popular tool of philanthropists, missionaries, and activists in the empire and the metropole to raise awareness and mobilize support from the British public. ${ }^{73}$ But the 1921 campaign was the first time the technology of the moving image was deployed for a humanitarian campaign. ${ }^{74}$ It became a new method of witnessing that would be used throughout the twentieth century in response to humanitarian catastrophes. ${ }^{75}$ In October 1921, George Mewes, a Daily Mail photographer, was sent to Russia with a film camera to record the reality of the famine as it happened. He returned in December with heartrending footage of starving children and bodies being buried. In early January 1922, Save the Children publicized the film in newsreels shown to audiences across Britain. ${ }^{76}$

Visual representations were not the only technique British organizations used to establish the credibility of their relief. Another method was to present a humanitarian

${ }^{69}$ See also Boucher, "Cultivating Internationalism"; Linda Mahood and Vic Satzewich, "The Save the Children Fund and the Russian Famine of 1921-23: Claims and Counter-Claims about Feeding Bolshevik Children," Journal of Historical Sociology 22, no. 1 (March 2009): 55-83.

${ }^{70}$ On humanitarian narratives and the mobilization of empathy see Thomas Laqueur, "Body, Detail, and the Humanitarian Narrative," in New Cultural History, ed. Lynn Hunt (Berkeley, 1989), 176-204.

${ }^{71}$ For example, see "The Russian Famine: Moment Ill-Chosen to Appeal for Fund"; "Save the Children in Russia: Huge Sum for a Dubious Famine," Daily Express, 18 November 1921; "The Famine within Our Gates"; "Feeding the Red Guards."

${ }^{72}$ On the history of humanitarian films see Michelle Tusan, "Genocide, Famine and Refugees on Film: Humanitarianism and the Great War," unpublished paper. On humanitarian imagery more generally see Christina Twomey, "Framing Atrocity: Photography and Humanitarianism," History of Photography 36, no. 3 (August 2012): 255-64; and Heide Fehrenbach and Davide Rodogno, eds., Humanitarian Photography: $A$ History (New York, 2015).

${ }^{73}$ Davis, Late Victorian Holocausts, 25-176. For the story of the metropole see Seth Koven, Slumming: Sexual and Social Politics in Victorian London (Princeton, 2004). On the creation of a Visual Instruction Committee in 1902, see Vernon, Hunger, 33-38.

${ }^{74}$ In that respect humanitarian films should be considered as part of the history and development of humanitarian forensic science. On forensics, see Thomas Keenan, Fables of Responsibility: Aberrations and Predicaments in Ethics and Politics (Stanford, 1997); Georges Didi-Huberman and J. M. Charcot, Invention of Hysteria: Charcot and the Photographic Iconography of the Salpêtrière (Cambridge, MA, 2003); Ludmilla Jordanova, The Look of the Past: Visual and Material Evidence in Historical Practice (Cambridge, 2012); and Thomas Keenan, Eyal Weizman, and Portikus (Gallery), Mengele's Skull: The Advent of a Forensic Aesthetics (Berlin, 2012).

${ }^{75}$ Later in the year Mewes was also sent back to Russia. In Council Minutes Ml/2, 1921, SCFA.

${ }^{76}$ See discussion in EJ 198/410, SCFA. The film raised over $£ 6,000$ from showings. Rodney Breen, "Saving Enemy Children-Save the Children's Russian Relief Organization, 1921-1923," Disasters 18, no. 1 (September 1994): 221-37. 
narrative that relied heavily on the use of facts, numbers, and technical experts in order to articulate the extent of Russian suffering. ${ }^{77}$ Quantitative data and comparisons with the British experience in India offered a way to establish truth and clarify that the famine was not a result of food mismanagement or Russian political maneuvers. While advocating for Russian relief, many MPs used a scale based on imperial famines. The Liberal MP Herbert Fisher argued that it would not be an exaggeration to say that in order to find parallels to the conditions in Russia "we have to go back to the great Indian famine of the eighteenth century, the famine which ravaged Bengal in 1770 and which carried off no fewer than 10,000,000 inhabitants of that teeming population."78 Others argued that even in India, the British had not known "such a famine with such devastating results."79 As Lord Cecil argued, using knowledge gained through the Indian famines might help determine "whether there has ever been any instance of distress comparable with this that now exists in Russia, and whether it is not the opinion of Indian experts that in India we do not know what famine means compared to what it is in Russia." 80 The British experience of famine in India offered a way to establish trust in a humanitarian mission beyond national and imperial borders.

\section{THE FAMINE EXPERT}

No other person, however, was more instrumental to the relief mission than Sir Benjamin Robertson, who was deputed to Russia in January 1922. As a former colonial administrator, Robertson was considered a leading authority on famines. ${ }^{81} \mathrm{He}$ gained his experience as a famine commissioner under Curzon, ${ }^{82}$ before he was appointed chief commissioner of the Central Provinces from 1912 to 1920 . On Sunday 8 January 1922, six months after the international relief mission began, Robertson was sent to the famine areas of the Volga region at the request of the British Russian Famine Relief Fund and the British Red Cross. ${ }^{83}$ Serving as a quasi-international inspector, his mission was to establish the severity of the

77 Thomas Laqueur, "Mourning, Pity, and the Work of Narrative in the Making of Humanity," in $H u$ manitarianism and Suffering: The Mobilization of Empathy, ed. Richard Ashby Wilson and Richard D. Brown (Cambridge, 2008), 31-57.

${ }^{78}$ Herbert Fisher, Speech to the House of Commons, 17 March 1922, Parliamentary Debates, Commons, 5th series, vol. 151 (1922), cols. 2545-626.

${ }^{79}$ Donald Maclean, Speech to the House of Commons, 17 March 1922, Parliamentary Debates, Commons, cols. 2545-626. Similar claims were made by Gilbert Murray, "The European Famine," Contemporary Review, 1 January 1919. See also Michael Asquith, Famine: Quaker Work in Russia 1921-23 (London, 1943).

${ }^{80}$ Lord Robert Cecil, Speech to the House of Commons, 9 March 1922, Parliamentary Debates, Lords, 5 th series, vol. 151 (1922), cols. 1462-65.

${ }^{81}$ Gardner, "Russian Famine the Worst"; the Lord Archbishop of Canterbury, Speech to the House of Lords, 23 February 1922, Parliamentary Debates, cols. 213-31.

${ }^{82}$ Lord Curzon, Speech to the House of Lords, 23 February 1922, Parliamentary Debates, cols. 213-31.

${ }^{83}$ The Imperial War Relief Fund in fact was searching for a British commissioner and had been in touch with Robertson since November 1921. See "The Imperial War Relief Fund," Russian Life, November 1921, 88/11, Hoover Archives (hereafter HA). Similarly, the Americans have been in touch with Robertson since that month as exemplified in the letter from Mowatt M. Mitchell, the American Relief Administration European Children Fund to Sir Benjamin Robertson, 21 November 1921, 88/11, HA. 
famine and to provide a method to relieve it. Together with a translator, J. F. Dyer, and John Gorvin, Nansen's representative on the International Russian Relief Executive, he traveled to the British- and American-led refugee camps and kitchens in Saratov; the Society of Friends relief operation in Buzuluk; and the Swedish Red Cross Mission in Samara, and to homes in the area similarly run by the American and Soviet relief teams. ${ }^{84}$

Robertson soon established that the importance of the relief mission was not only ethical but also economic, necessary to stabilize the region. ${ }^{85}$ His inspection covered technical issues-for example, to confirm that the warehouses were substantial, weatherproof buildings and were protected by the local Soviet authorities-and also had a political dimension to verify that the Russians did not abuse the aid. ${ }^{86}$ He met with the Soviet authorities in Moscow and with the heads of the villages around Saratov to determine if relief was well coordinated in the famine zones. ${ }^{87}$ Unlike India, where the government could rely on private wheat dealers, Robertson later contested, in Russia trade was limited to the state. "As a matter of fact there is plenty of wheat in Russia," he argued, ${ }^{88}$ but the new communist system limited private enterprises and weakened the state's ability to aid its citizens in the Saratov region. Once one of the richest areas of wheat in the country and a major supplier of food to Europe, the famine zone of Saratov was now completely impoverished. ${ }^{89}$ Although famine likewise prevailed in Ukraine at this time, it was here, Robertson emphasized, that the webs of relief should be forged. ${ }^{90}$

Robertson also helped to forge trust in the new voluntary and international humanitarian apparatus, which, although it had been operating on a small scale in Central and Eastern Europe since 1919, nevertheless had very limited experience for such a large relief mission. For example, between 10 and 13 January 1922, Robertson visited Save the Children in Saratov, which became operational for the first time during the Russian famine, and he met with Lawrence Webster, the charity's Russian operative. ${ }^{91}$ Webster was in charge of Save the Children food distribution on the ground and was also given responsibility for a small staff of relief workers and for negotiations with the local Russian authorities. Robertson provided

\footnotetext{
${ }^{84}$ See "Briton Praises A. R. A. Relief Work."

85 Thus Robertson joined some of the proponents in Britain who saw in the relief mission an economic necessity, not only a humanitarian one. H. N. Brailsford from the Imperial War Relief Fund to William Beveridge on 27 February 1922, BEVERIDGE/7/90/4, LSEA.

${ }^{86}$ According to the Robertson report, only around 0.5 percent of the British flour sent to Saratov was stolen. Ibid.

${ }^{87}$ Benjamin Robertson, "Notes from Russian Visit," February 1922, EJ198, SCFA.

88 "Briton Praises A. R. A. Relief Work."

${ }^{89}$ Thus Robertson joined some of the proponents in Britain who saw in the relief mission an economic necessity and not only a humanitarian one. H. N. Brailsford from the Imperial War Relief Fund to William Beveridge, 27 February 1922, BEVERIDGE/7/90/4, LSEA.

${ }^{90}$ Wasyl Veryha, A Case Study of Genocide in the Ukrainian Famine of 1921-1923: Famine as Weapon (Lewiston, 2007); Douglas Tottle, Fraud, Famine and Fascism: The Ukrainian Genocide Myth from Hitler to Harvard (Toronto, 1987). See also Benjamin Robertson, The Famine in Russia: Report (London, 1922); See also Press Release, All-British Appeal, undated c. March 1922, 88/11, HA.

${ }^{91}$ See C. J. C. Quinn of the American Relief Administration to the London Headquarters, 11 March 1922, reporting on the Save the Children's relief plan and using the charity's data for the American Relief Administration's relief work in 88/11, HA; D. B. Kinne, district supervisor American Relief Administration to the American Relief Administration director in Moscow, 4 March 1922, 88/11, HA.
} 
Webster with the guidelines for Save the Children's relief methods and ways of distributing food. ${ }^{92} \mathrm{He}$ also inspected the stock books and ledgers and made sure to report to Britain that the charity's aid workers in Saratov kept a full record of the balance and receipts for its supplies.

Robertson's advice focused on maximizing efficiency while managing and feeding the starving population. He also emphasized the danger of famine wanderers and famine refugees, who, he argued, carried the potential for political unrest, especially in a postrevolutionary Russia. He was critical, not only of the Soviets management of the famine camps, but also of the British and American relief solutions to these conditions, which he thought focused solely on feeding children and not enough on adults. As his report would later emphasize, the humanitarian organizations in Saratov, Samara, and Buzuluk neglected adults. "It is obvious that the evil should be attacked at once at its source by the extended feeding of children and adults, in the villages," he argued, "so as to prevent starving people wandering aimlessly in search of food." The purpose of feeding adults therefore was both ethical and political, namely a method to control the emaciated population. ${ }^{93}$

Similarly, Robertson advised the relief centers to organize their aid into systematic categories based on location and need. From children in orphanages and refugee camps to those in their own homes and in towns, these categories reflected the Victorian hierarchy of poverty. Robertson was particularly impressed by the American system of relief. According to him, "the policy in India for twenty-five years [was] to insist that children receiving food consume it at the feeding points." The American adult soup kitchens "were conducted on the same principle." checked the nutritional values and calories given to children (no more than $720 \mathrm{cal}-$ ories, and in the case of Save the Children, for example, arranged in a three-day cycle), whether the food was cooked and examined, and whether it was distributed systematically and uniformly. ${ }^{95}$ Finally, he examined whether these relief organizations had kept records of food distribution, and he made sure that the starving population (and children between the ages of seven and fourteen in particular) were not getting more rations than they supposedly "deserved." Thus the old Victorian ethic of hunger developed in colonial Ireland and India, as well as in England, became the underlying logic of both British and international relief.

When he returned from Russia, Robertson was appointed the high commissioner of the Russian Famine Relief Fund. His report was highly celebrated in Westminster and in the British press. 96 "Drawing upon the great fund of his administrative experience in India," the Daily Telegraph declared, Robertson "has rendered invaluable service by co-ordinating the work of various British organisations and making them fit into the limits of one general scheme. ${ }^{\prime 97}$ Based on his recommendations,

92 "Opinion de Sir Benjamin Robertson Sur l'Oeuvre de l'U. I. S. E. en Russie," LUnion Internationale de Secours aux Enfants, Troisième Année, 5-6, 29-28 February 1922.

${ }^{93}$ Robertson, "Notes from Russian Visit."

${ }^{94}$ Fisher, The Famine in Soviet Russia, 103.

${ }^{95}$ For the science of nutrition in this period see Vernon, Hunger. See also Nick Cullather, "The Foreign Policy of the Calorie," American Historical Review 112, no. 2 (April 2007): 337-64.

96 Correspondent, "Russian Famine." See also the Lord Archbishop of Canterbury, Speech to the House of Lords, 23 February 1922.

97 Correspondent, "The Russian Famine." 
the British relief in Russia was consolidated through the All-British Appeal to unify and maximize its reach. ${ }^{98}$

Robertson's advice helped formalize the cooperation between governmental and nongovernmental humanitarian aid. Based on his report, the All-British Appeal applied for a grant from the British public through government funds. ${ }^{99}$ While the government granted the appeal with only a "gift in kind" of bully beef and lime juice left over from the war and worth just $£ 50,000$ (10 percent of the initial request), it still confirmed the legitimacy of their work. ${ }^{100}$ Despite the objections of members of parliament like Neville Chamberlin and John Rees, who contended that it was not right for Britain to become a "Mrs. Jellyby among the nations," Robertson's report helped set two precedents for official support of humanitarian aid. ${ }^{101}$ First, by authorizing this grant, Robertson and the All-British Appeal had established that the British government would provide aid to foreign nationals. Although the government had previously provided grants to the British Red Cross to assist British nationals and soldiers overseas, it had never given a "grant in aid" to a foreign nation. While the U.S. Congress had done so since 1918, Britain and the other Allied powers had instead granted trade credits to impoverished nations such as Austria, thereby allowing their governments to purchase food through loans. ${ }^{102}$ Second, Robertson's expertise helped establish a precedent in which the British government would distribute its aid through such voluntary organizations as Save the Children.

Robertson's report also had a broad international impact. Based on his recommendations, the American, Swedish, and the League of Nations' teams reconfigured their modes of food distribution. Robertson advised the International Russian Relief Executive team in Geneva, for example, on how to account for their supplies. While the British and the Swedish in Saratov and Samara distributed these supplies, he noted, there was no systematic method to account for their quantities. Robertson was also highly critical of the types of food sent to the famine area. In his view, supplies should be kept to staples such as unmilled grain, wheat, rice, beans, and peas, which are "suitable for famine relief," rather than herring or lime juice, which could not be distributed properly. Finally, Robertson's recommendations on feeding adults and rations were adopted by other international aid teams. Robertson worked with American Relief Administration aid workers in the famine zones on how to adapt their current supplies to the British science of famine relief. ${ }^{103}$ Upon his return to

\footnotetext{
${ }^{98}$ Save the Children was at first reluctant to join but toward March 1922 became part of the appeal. Council Minutes, 3 March 1922, Ml/2, SCFA; "Russian Famine Relief. British Societies to Combine," Times, 1 March 1922.

${ }^{99}$ In a speech he gave in Liverpool on 25 February, Robertson declared that the British mission would have supplies until April that year. He announced that the All-British Appeal would need an additional sum of five hundred thousand pounds. See Benjamin Robertson, Notes from Speech, 25 February 1922, $88 / 11$, HA.

100 TNA, To the Chancellor of the Exchequer (undated, c. November 1921), G. Barton to Montgomery, 16 December 1921, T161/164 15175/1; House of Commons, Oral Answers to Questions, 9 November 1921, Parliamentary Debates, Commons, 5th series, vol. 148 (1921), cols. 393-96.

${ }^{101}$ Supply Committee, House of Commons, 17 March 1922, Parliamentary Debates, Commons, 5th series, vol. 151 (1922), cols. 2545-626.

${ }^{102}$ House of Commons, Oral Answers to Questions, "Russia (Famine Relief)," 16 February 1922, Parliamentary Debates, Commons, 5th series, vol. 150 (1922), cols. 1203-4; House of Commons, Oral Answers to Questions, 9 November 1921.

${ }^{103}$ Fisher, The Famine in Soviet Russia, 103.
} 
London he also met with Walter Brown, the American Relief Administration's director for Europe, and reported to him about the work the Americans were doing in the field. Writing to William Haskell, the American Relief Administration's director in Moscow, Brown admitted, “it was gratifying to me to have [Robertson's] views as a layman." 104 Even after his visits, organizations such as the American Relief Administration kept in touch with Robertson and the rest of the British units, requesting his advice and knowledge on the famine conditions. ${ }^{105}$ Thus, with Robertson's guidance, systematic humanitarian knowledge came to shape the ways in which national and international agencies provided foreign aid.

\section{CONCLUSION}

In July 1922 Robertson announced that his task as chairman of the United Russian Famine Relief Committee was complete. "[T] he great famine in the districts covered by the British organizations," he claimed, "has been broken at last." 106 It was now up to the Soviet government "to prove its competence to assist the people under its rule." 107 While famine persisted in some spots of the country-like the southern end of the Ukraine and the inner Urals-Robertson proclaimed that the term of British relief had met its goals. On 17 July, after consulting with Robertson the American Relief Administration followed suit and ceased providing relief. ${ }^{108}$ Robertson helped to define not only the onset of emergency but also its end.

Britain's experience during the Russian famine had a long-lasting impact on the voluntary sector in Britain and beyond. In particular, Robertson's advice and guidance influenced Save the Children and the Quakers' relief organization as they were transitioning to large-scale aid operations in Europe. A manual on famine relief written during the Second World War cited the Russian famine of 1922 as a transformative experience and a source of knowledge for the Society of Friends. The Society of Friends, which was highly instrumental in the formation of Oxfam in 1942, echoed the lessons learned from Robertson about managing relief houses and camps at minimum costs and the importance of collaborating with the British government. ${ }^{109}$ Similarly, British aid workers, like Melville Mackenzie, who gained their knowledge in Russia, later went on to work for the League of Nations and the United Nations. ${ }^{110}$ Furthermore, imperial expertise became a way to legitimize

${ }^{104}$ Walter Brown to William Haskell, 28 February 1922, 88/11, HA.

105 See G. I. Gay of the ARA to Robertson, 14 February 1922, 88/11, HA; Brown to Haskell, 14 March 1922, 88/11, HA; Walter Lyman Brown to Benjamin Robertson, 16 April 1922, 88/11, HA; Mowatt M. Mitchell of the American Relief Administration to Benjamin Robertson, 20 July 1922, 88/11, HA.

106 Correspondent, "The Russian Famine."

107 Robertson to the Times, 1 January 1923.

${ }^{108}$ Mowatt M. Mitchell of the American Relief Administration to Benjamin Robertson, 17 July 1922 , $88 / 11$, HA.

${ }^{109}$ Asquith, Famine.

${ }^{110}$ Melville Mackenzie, a Quaker doctor working on the Russian famine in 1922, joined the League of Nations in 1928 and in 1944 became the chairman of the European Health Committee of the United Nations Relief and Rehabilitation Administration. See Melville D. Mackenzie, "Some Practical Considerations in the Control of Louse-borne Typhus Fever in Great Britain in the Light of Experience in Russia, Poland, Rumania and China," Proceedings of the Royal Society of Medicine 35, no. 2 (December 1941): 141-56. 
the humanitarian mission and establish the credibility of the emerging voluntary sector. This voluntary sector, however, was not divorced from state funding and interests. Instead, based on the imperial model, British experts forged a "mixed economy" that combined voluntary with state aid. This close relation between governmental and nongovernmental aid would leave its mark throughout the twentieth century. Nongovernmental humanitarianism became infused with governmental interests.

Through humanitarian aid Britain assumed a new role on a global stage. Imperial knowledge and expertise gave the international mission the technologies necessary to organize large-scale relief. At the same time, it created a type of humanitarian aid that replicated and reproduced colonial ethics. British experts and officials such as Curzon, Hill, and Robertson came to shape the organization of the international relief movement. Based on their experience of famine relief in Britain's Empire, these experts planned and advised British agencies-and those of other nationson how to distribute their food aid, plan their rations, and organize their relief camps. As such, their advice replicated hierarchies of relief, which quantified the scales of suffering and sought to provide the minimum level of relief for the maintenance of the suffering population without making them dependent. The lessons learned in the Russian famine would come to shape the development of a "humanitarian reason" throughout the twentieth century. ${ }^{11}$ Modern humanitarianism was born from empire rather than from its loss.

${ }^{111}$ Fassin, Humanitarian Reason, 1-21. 